\title{
REGIONAL VARIABILITY OF SURFACE OCEAN RADIOCARBON FROM SOUTHERN GREAT BARRIER REEF CORALS
}

\author{
ELLEN R. M. DRUFFEL and SHEILA GRIFFIN \\ Department of Earth System Science, University of California, Irvine, California 92717 USA
}

\begin{abstract}
High-precision $\Delta^{14} \mathrm{C}$ and stable isotope $\left(\delta^{18} \mathrm{O}\right.$ and $\left.\delta^{13} \mathrm{C}\right)$ records are reported for post-bomb corals from three sites off the eastern Australian coast. We observe that $\Delta^{14} \mathrm{C}$ values increased from ca. $-50 \%$ in the early $1950 \mathrm{~s}$ to $+130 \%$ by 1974 , then decreased to $110 \%$ by 1991 . There is general agreement between the coral results and $\Delta{ }^{14} \mathrm{C}$ of dissolved inorganic carbon (DIC) in seawater measured previously for locations in the South Pacific. $\Delta^{14} \mathrm{C}$ values at our southern hemisphere sites increased at a slower rate than those observed previously in the northern hemisphere. Small variations in the $\Delta^{14} \mathrm{C}$ records among our three sites are likely due to differences in circulation between the shallow coastal waters and the open ocean influenced by seasonal upwelling. Low $\Delta^{14} \mathrm{C}$ is associated with most El Niño/Southern Oscillation (ENSO) events after 1970, indicating input of low ${ }^{14} \mathrm{C}$ waters from the southern-shifted South Equatorial Current. The exception is the severe ENSO event of 1982-1983 when upwelling in the South Equatorial Current could have ceased, causing normal $\Delta^{14} \mathrm{C}$ values in the corals during this time.
\end{abstract}

\section{INTRODUCTION}

Corals offer windows into the past, allowing us to study chemical and physical properties of seawater, habitat and climate. Corals accrete an aragonitic skeleton at a rate of $3-25 \mathrm{~mm} \mathrm{yr}^{-1}$; this facilitates seasonal sampling in most specimens. The coral's mineral structure is rigid, and not influenced by such processes as bioturbation. It is possible that some coral colonies live for thousands of years. The introduction of uranium-thorium (U-Th) dating by thermal ionization mass spectrometry has enabled corals to be dated with very high accuracy (Edwards, Chen and Wasserburg 1987) back through the last interglacial period and beyond.

Radiocarbon measurement of a banded coral reveals the ${ }^{14} \mathrm{C} /{ }^{12} \mathrm{C}$ ratio of the dissolved inorganic carbon (DIC) in the seawater that surrounded the coral at the time of accretion. Coral ${ }^{14} \mathrm{C}$ records for the surface Atlantic and Pacific Oceans during the past several hundred years have been reported previously (Druffel and Linick 1978; Druffel 1987; Nozaki et al. 1978; Toggweiler, Dixon and Broecker 1991). Alternatively, oxygen isotope records in banded corals $\left(\delta^{18} \mathrm{O}\right)$ are controlled by two factors, water composition (i.e., seawater salinity) and seawater temperature at the time of accretion. Stable carbon isotope ratios $\left(\delta^{13} \mathrm{C}\right)$ are influenced by several factors, including water mass $\left(\delta^{13} \mathrm{C}\right.$ of DIC), reproductive status and metabolic effects.

${ }^{14} \mathrm{C}$ levels in surface seawater vary as a function of two major processes. First, mixing with surrounding surface waters or subsurface waters that contain lower $\Delta^{14} \mathrm{C}$ signatures acts to change the surface $\Delta^{14} \mathrm{C}$ levels. Second, gas exchange of $\mathrm{CO}_{2}$ at the air-sea interface allows higher $\Delta^{14} \mathrm{C} \mathrm{CO}_{2}$ from the atmosphere to enter the DIC pool in surface seawater. Hence, if the amount of lateral and vertical mixing and the gas exchange rate between the atmosphere and ocean have remained the same, ${ }^{14} \mathrm{C}$ levels in a given water mass should remain constant over time. This is not the case for the Southwest Pacific over the last 350 yr (Druffel and Griffin 1993).

\section{METHODS}

All coral samples used for this project were Porites australiensis, an abundant species that grows in the Great Barrier Reef. Corals were collected from a depth of $10-12 \mathrm{~m}$ in Abraham Reef (in the Swains Reef complex, $\left.22^{\circ} \mathrm{S}, 153^{\circ} \mathrm{E}\right)$, Heron Island $\left(23^{\circ} \mathrm{S}, 152^{\circ} \mathrm{E}\right)$ and Lady Musgrave Island $\left(24^{\circ} \mathrm{S}\right.$, $153^{\circ} \mathrm{E}$ ). At Abraham Reef, two cores, $10 \mathrm{~cm}$ in diameter, were taken from the top of an 8-m-high colony at $10 \mathrm{~m}$ water depth; the first core (Abraham-1) was drilled in December 1985, and the sec- 
ond (Abraham-2) in May 1991. At Heron Island, cores were taken in November 1983 from small colonies (1-2 $\mathrm{m}$ in diameter) in the region outside the lagoon. At Lady Musgrave Island, a single colony that grew outside of the lagoon was cored in November 1983. Methods used to clean, X-ray and section the corals were reported previously (Griffin and Druffel 1985).

Annual coral bands were taken from all specimens and subjected to ${ }^{14} \mathrm{C}$ analysis. In these corals, high-density bands accrete from October to December of each year. The bands were cut on the leading edge of the high-density bands; hence, the midpoint of each band was approximately March of the year reported (i.e., 19XX.3). There are several samples from the Abraham-1 core that contained $70 \%$ of one year and $30 \%$ of the band one year younger; thus, the mid-points were 19XX.6 for the years 1961-1970.

We acidified ca. $25 \mathrm{~g}$ of coral (aragonite) to produce 5 liters of $\mathrm{CO}_{2}$ gas. The gas samples were converted to acetylene gas via a lithium carbide intermediate and purified through charcoal at $0^{\circ} \mathrm{C}$. Each sample was counted for 6-7 two-day periods in 1.5-liter quartz, gas proportional $\beta$ counters according to standard procedures (Druffel and Griffin 1993; Griffin and Druffel 1985).

${ }^{14} \mathrm{C}$ results for the annual coral samples are reported as $\Delta^{14} \mathrm{C}$ in Table 1 . Uncertainties reported for the $\Delta^{14} \mathrm{C}$ measurements include both counting statistics and laboratory reproducibility uncertainties. The average statistical counting uncertainty of each analysis is $\pm 2.1 \%$, and includes background and standard (HOxI) measurement uncertainties and the $\delta^{13} \mathrm{C}$ correction. The laboratory reproducibility uncertainty was determined from multiple, high-precision analyses of a modern coral standard. The standard deviation of 10 results, each with a statistical uncertainty of $2.1 \%$ was $3.0 \%$. Thus, at this precision level, the laboratory uncertainty constitutes $c a .40 \%$ additional uncertainty. Therefore, to obtain our total uncertainty, we multiply the statistical uncertainty by 1.4 . The $\delta^{13} \mathrm{C}$ values, measured on the reburned acetylene gas, were used to correct the $\Delta^{14} \mathrm{C}$ results according to standard techniques (Stuiver and Polach 1977). All seasonal $\delta^{13} \mathrm{C}$ and $\delta^{18} \mathrm{O}$ measurements were performed according to standard techniques (Druffel and Griffin 1993). Stable isotope results obtained for this study were performed on a VG Micromass $602 \mathrm{E}$ isotope ratio mass spectrometer, with uncertainties of $\pm 0.1 \%$ for both measurements.

\section{RESULTS}

Figure 1 shows the $\Delta^{14} \mathrm{C}$ results for our three Australian corals. Prior to the introduction of bombproduced ${ }^{14} \mathrm{C}$ to the oceans, coral $\Delta{ }^{14} \mathrm{C}$ values averaged $-50 \%$. The average pre-bomb value at Heron Island $(-49.8 \pm 4.5 \%$ sd, $\mathrm{N}=5)$ was slightly higher, and more variable, than that at Abraham Reef $(-53.8 \pm 2.0 \%$ sd, $\mathrm{N}=5) . \Delta^{14} \mathrm{C}$ values increased steadily after 1958 to $c a$. $110 \%$ by 1970 , then rose at a reduced rate through the 1970 s. $\Delta{ }^{14} \mathrm{C}$ values decreased at Abraham Reef after 1980 from $130 \%$ to $110 \%$ by 1991 .

Figures $2 \mathrm{~A}$ and $2 \mathrm{~B}$ show the seasonal stable isotope data $\left(\delta^{13} \mathrm{C}\right.$ and $\left.\delta^{18} \mathrm{O}\right)$ obtained for Heron and Lady Musgrave Islands. The $\delta^{18} \mathrm{O}$ values for Heron Island coral average $-4.5 \%$ throughout the 28 yr record. There are poorly defined seasonal patterns that range from $0.3 \%$ to $0.7 \%$. The $\delta^{13} \mathrm{C}$ values for Heron Island coral average $-0.7 \%$, with a significant increase of values observed in the later part of the record. The $\delta^{13} \mathrm{C}$ record appears to have a better-defined seasonal signal (with variations that range from $0.4-1.3 \%$ ) than the $\delta^{18} \mathrm{O}$ record. Unlike the Heron coral, $\delta^{18} \mathrm{O}$ values for Lady Musgrave coral show well-defined, annual variations of $0.4 \%$ - $0.8 \%$. The $\delta^{13} \mathrm{C}$ values for Lady Musgrave coral show annual variations (0.8-1.3\%o) larger than those observed for Heron Island, but no long-term change. 
TABLE $1 .{ }^{14} \mathrm{C}$ values for Abraham Reef, Heron Island and Lady Musgrave Corals, 1950-1991. All $\triangle^{14} \mathrm{C}$ values are for 1 -yr coral bands, except those for 1952.8 and 1968.1 for Heron Island and Abraham 1, respectively, that represent $\Delta^{14} \mathrm{C}$ values for 2 -yr coral bands.

\begin{tabular}{|c|c|c|c|c|c|c|c|c|}
\hline $\begin{array}{l}\text { Year } \\
(\mathrm{AD}) \\
\end{array}$ & $\begin{array}{l}\text { Heron } \\
\text { Island } \\
\left(\Delta^{14} C\right) \\
\end{array}$ & $\begin{array}{l}\text { WH- } \\
\text { no. }\end{array}$ & $\begin{array}{c}\text { Abraham } 1 \\
\left(\Delta^{14} \mathrm{C}\right) \\
\end{array}$ & $\begin{array}{l}\text { WH- } \\
\text { no. }\end{array}$ & $\begin{array}{c}\text { Abraham } 2 \\
\left(\Delta^{14} C\right)\end{array}$ & $\begin{array}{l}\text { WH- } \\
\text { no. }\end{array}$ & $\begin{array}{c}\text { Lady } \\
\text { Musgrave } \\
\left(\Delta^{14} \mathrm{C}\right) \\
\end{array}$ & $\begin{array}{l}\text { WH- } \\
\text { no. }\end{array}$ \\
\hline 1950.3 & -52.4 & 360 & -52.2 & 811 & & & & \\
\hline $\begin{array}{l}1951.3 \\
1952.8\end{array}$ & -47.5 & 379 & -55.4 & 1187 & & & & \\
\hline $\begin{array}{l}1952.8 \\
1953.3\end{array}$ & -449 & 334 & -56.5 & 1083 & & & & \\
\hline 1954.3 & -47.7 & 383 & -52.1 & 1188 & & & & \\
\hline 1955.3 & -56.3 & 403 & -53.0 & 1064 & & & & \\
\hline 1956.3 & -44.8 & 393 & & & & & -51.8 & 751 \\
\hline 1957.3 & -37.9 & 401 & -51.2 & & & & & \\
\hline 1958.3 & -39.4 & 398 & -44.2 & 1183 & & & -52.9 & 724 \\
\hline 1959.3 & -32.0 & 404 & -43.0 & 1067 & & & & \\
\hline $\begin{array}{l}1960.3 \\
19613\end{array}$ & -28.8 & 403 & & & & & -25.4 & 518 \\
\hline $\begin{array}{l}1961.3 \\
1961.6\end{array}$ & -21.1 & 382 & -13.7 & 1178 & & & -24.4 & \\
\hline 1962.3 & -29.2 & 726 & & & & & & \\
\hline 1962.6 & & & -13.7 & 1344 & & & & \\
\hline 1963.3 & 7.4 & 333 & & & & & -6.7 & 529 \\
\hline $\begin{array}{l}1963.6 \\
1964.3\end{array}$ & 20.8 & 719 & 21.0 & 900 & & & & \\
\hline 1964.6 & & & 43.0 & 824 & & & & \\
\hline 1965.3 & 46.8 & 397 & & & & & 37.4 & 527 \\
\hline 1966.3 & 67.6 & 388 & & & & & & \\
\hline $\begin{array}{l}1967.3 \\
1968.1\end{array}$ & 80.2 & 361 & & & 67.8 & 1367 & 70.2 & 523 \\
\hline $\begin{array}{l}1968.1 \\
1968.3\end{array}$ & 97.7 & 378 & 81.7 & 584 & 93.3 & 1375 & & \\
\hline 1969.3 & 104.9 & 391 & & & & & 103.7 & 519 \\
\hline 1970.3 & 109.4 & 707 & & & 101.5 & 1370 & & \\
\hline 1971.3 & 119.4 & 399 & & & & & 111.2 & 526 \\
\hline 1972.3 & 116.7 & 728 & & & 112.5 & 1357 & & \\
\hline 1973.3 & 118.4 & 332 & & & 105.3 & 1306 & 113.5 & 530 \\
\hline 1974.3 & 133.4 & 380 & & & 123.1 & 1372 & 123.2 & 524 \\
\hline 1975.3 & 128.9 & 749 & & & 124.6 & 1377 & & \\
\hline 1976.3 & 145.6 & 405 & & & 136.1 & 1373 & & \\
\hline 1977.3 & 116.0 & 723 & & & 124.0 & 1376 & & \\
\hline 1978.3 & 139.7 & 395 & 122.2 & 1346 & & & 144.7 & 521 \\
\hline 1979.3 & 129.8 & 718 & 136.7 & 1345 & & & & \\
\hline 1980.3 & 156.1 & 1405 & 131.7 & 1343 & & & 137.3 & 528 \\
\hline 1981.3 & 133.3 & 394 & & & & & 139.9 & 520 \\
\hline 1982.3 & & & 125.4 & 899 & & & 125.3 & 522 \\
\hline 1983.3 & 132.6 & 331 & 132.2 & 1339 & & & 121.6 & 525 \\
\hline $\begin{array}{l}1984.3 \\
1985 .\end{array}$ & & & & & 126.1 & 1365 & & \\
\hline $\begin{array}{l}1985.3 \\
1986.3\end{array}$ & & & & & 128.1 & 1359 & & \\
\hline $\begin{array}{l}1986.3 \\
1987.3\end{array}$ & & & & & 125.8 & 1374 & & \\
\hline 1988.3 & & & & & $\begin{array}{l}130.4 \\
119.4\end{array}$ & $\begin{array}{l}1369 \\
1368\end{array}$ & & \\
\hline 1989.3 & & & & & 119.2 & 1371 & & \\
\hline 1990.3 & & & & & 122.0 & 1358 & & \\
\hline 1991.1 & & & & & 109.9 & 1366 & & \\
\hline
\end{tabular}




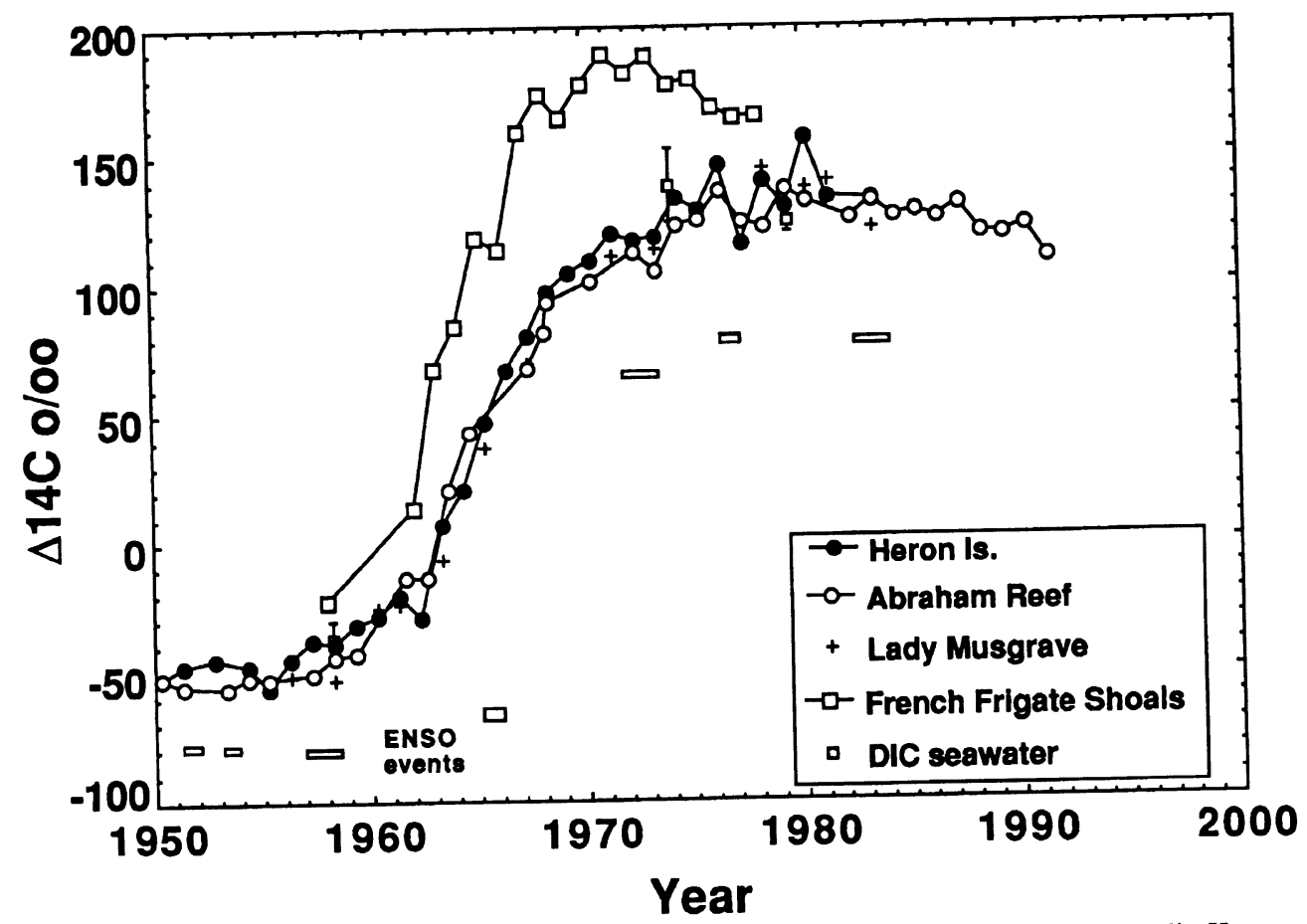

Fig. 1. $\Delta^{14} \mathrm{C}$ measurements in annual coral bands from three locations in the Great Barrier Reef, Australia: Heron Island, Abraham Reef and Lady Musgrave Island. The size of the points is approximately equal to $2 \sigma$ uncertainty of the $\Delta^{14} \mathrm{C}$ measurements. $\Delta^{14} \mathrm{C}$ measurements for coral from French Frigate Shoals $\left(23^{\circ} 43^{\prime} \mathrm{N}, 166^{\circ} 06^{\prime} \mathrm{W}\right)$ in the North Pacific are included as an example of a northern Pacific coral record (Druffel 1987). For comparison, average $\Delta^{14} \mathrm{C}$ results from seawater DIC collected by four groups of investigators are plotted as open squares with vertical bars that include 2- $\sigma$ uncertainty: 1) GEOSECS-January 1974, Stn $269\left[23^{\circ} 57^{\prime} \mathrm{S}, 174^{\circ} 31^{\prime} \mathrm{W}, 124 \pm 4 \% 0\right.$ at $5 \mathrm{~m}$ and $151 \pm 4 \%$ at $10 \mathrm{~m}$ ] and $S \operatorname{Stn} 263\left[16^{\circ} 41^{\prime} \mathrm{S}, 167^{\circ} 03^{\prime} \mathrm{W}, 138 \pm 4 \% 0\right.$ at $\left.10 \mathrm{~m}\right]$ (Östlund and Stuiver 1980); 2) FGGE Shuttle-April $1979,23^{\circ} \mathrm{S}, 150^{\circ} \mathrm{W}, 124 \pm 4 \% 0$ at $8 \mathrm{~m}$ (Quay, Stuiver and Broecker 1983); 3) March $1958,21^{\circ} \mathrm{S}, 173^{\circ} \mathrm{W},-40 \pm 4 \% \circ$ at $1 \mathrm{~m}$ (Rafter 1968); and 4) March 1958, $21^{\circ} 17^{\prime} \mathrm{S}, 177^{\circ} 29^{\prime} \mathrm{E},-36 \pm 6 \% 0$ at $0 \mathrm{~m}$; $20^{\circ} 52^{\prime} \mathrm{S}, 175^{\circ} 25^{\prime} \mathrm{W},-32 \pm 9 \% 0$ at $0 \mathrm{~m} ; 18^{\circ} 18^{\prime} \mathrm{S}, 172^{\circ} 21^{\prime} \mathrm{W},-38 \pm 5 \%$ at $0 \mathrm{~m}$ (Burling and Garner 1959).

\section{Discussion}

Comparison between the coral results and $\Delta^{14} \mathrm{C}$ of DIC in seawater from the South Pacific are shown in Figure 1. The $\Delta^{14} \mathrm{C}$ values from GEOSECS (Ostlund and Stuiver 1980), the FGGE Shuttle and earlier cruises (Burling and Garner 1959; Rafter 1968) agree within $2 \sigma$ of the Australian coral $\Delta^{14} \mathrm{C}$ record. This agreement demonstrates that the coral data is representative of an open ocean current that feeds the southern Great Barrier Reef area, namely the East Australian Current.

Significant differences among the three $\Delta^{14} \mathrm{C}$ records in Great Barrier Reef corals suggest regional variability. Figure 1 shows that $\Delta^{14} \mathrm{C}$ values for Heron Island are generally higher than those for Abraham Reef. Of the $17 \mathrm{yr}$ for which a significant difference $(>2 \sigma)$ between the two records is noticed, 11 of the Heron Island values are higher. Of the $6 \mathrm{yr}$ when Abraham Reef $\Delta^{14} \mathrm{C}$ is higher than the corresponding Heron Island values, $4 \mathrm{yr}$ lie between 1962 and 1965 when the bomb input to the ocean was at its maximum. Of the 12 Lady Musgrave Island $\Delta^{14} \mathrm{C}$ values, 11 are either equal to or less than the corresponding Heron Island values. This can be compared to the study of regional $\Delta^{14} \mathrm{C}$ in Bermuda corals, where $\Delta^{14} \mathrm{C}$ in north Bermuda waters was steadily higher than that in south Bermuda (Druffel 1989). 


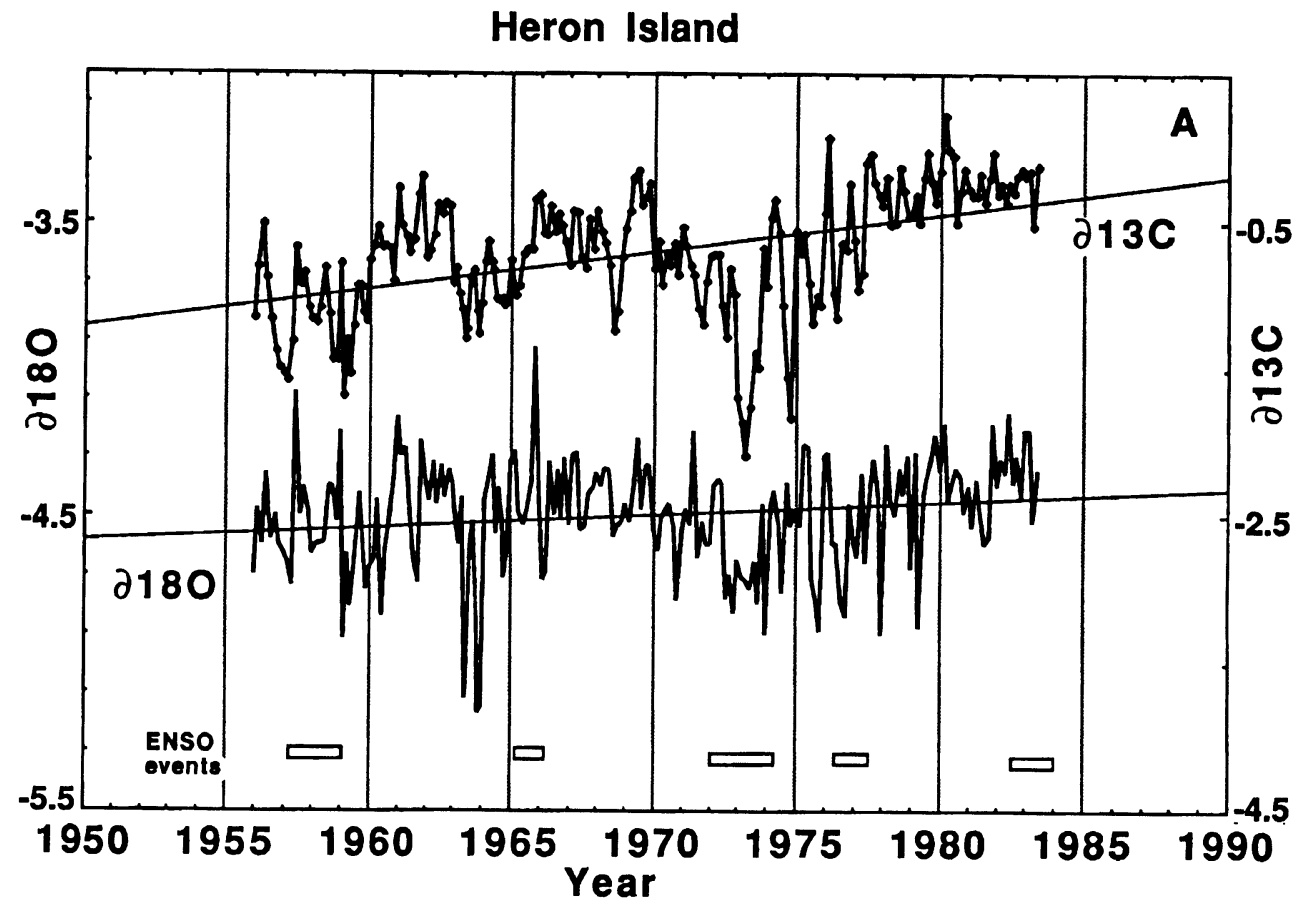

Lady Musgrave Island

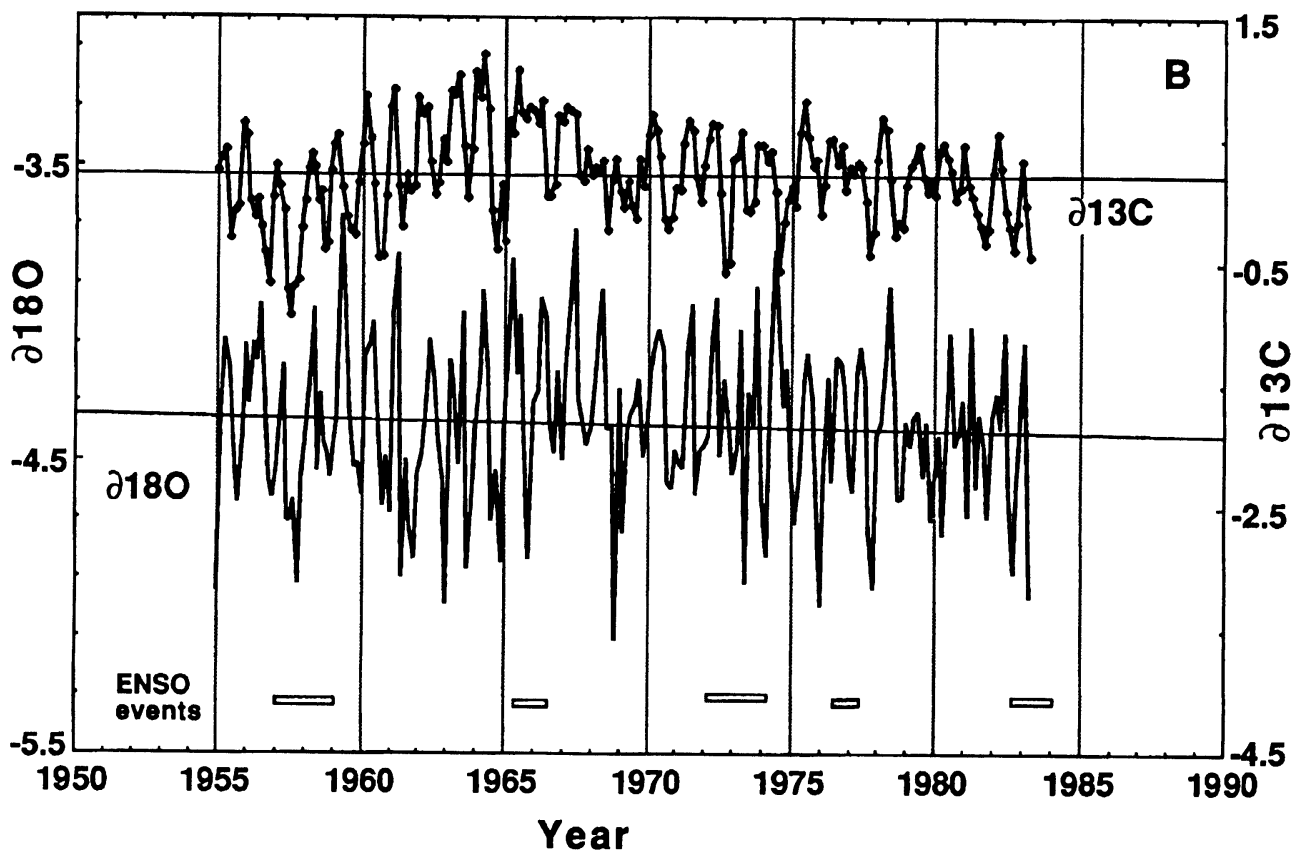

Fig. 2. $\delta^{13} \mathrm{C}$ and $\delta^{18} \mathrm{O}$ measurements in seasonal coral samples drilled from slabs of coral from (A) Heron Island and (B) Lady Musgrave Island. Samples were roasted in a vacuum for $1 \mathrm{~h}$ at $375^{\circ} \mathrm{C}$ just prior to stable isotope analysis to remove organic matter. 
The regional differences of $\Delta^{14} \mathrm{C}$ noticed here are most likely related to the general circulation patterns in these areas and their proximity to sources of upwelled (low- $\Delta^{14} \mathrm{C}$ ) water. Figure 3 illustrates the locations of each of our coral sites. Heron is an inner island in the southern Great Barrier Reef, located $40 \mathrm{~km}$ from the coast. The predominant flow in this region is from the north-northwest, and contains a relatively larger amount of Coral Sea water than locations to the east. Abraham Reef is located on the southeastern tip of the outer Great Barrier Reef, $200 \mathrm{~km}$ offshore of the Queensland coast. It lies close to the shelf break where upwelling has been observed (Andrews and Gentien 1982). The predominant flow in this region is from the westward East Australian Current (EAC). Hence, we assert that Abraham Reef is influenced by lower $\Delta^{14} \mathrm{C}$ water from upwelling. Heron Island, in contrast, is laved by non-upwelling waters from the northern coast and Coral Sea. The depth of the water column along most of the coastal traverse is $<100 \mathrm{~m}$, which makes it difficult to invoke entrainment of low $\Delta^{14} \mathrm{C}$ waters into the surface near Heron Island. Thus, the $\Delta^{14} \mathrm{C}$ of these waters is likely to increase slightly in transit by incorporation of high $\Delta^{14} \mathrm{C} \mathrm{CO}_{2}$ from the atmosphere. A model of the carbon isotope balance of this area is the subject of a separate publication (Druffel, ms.).

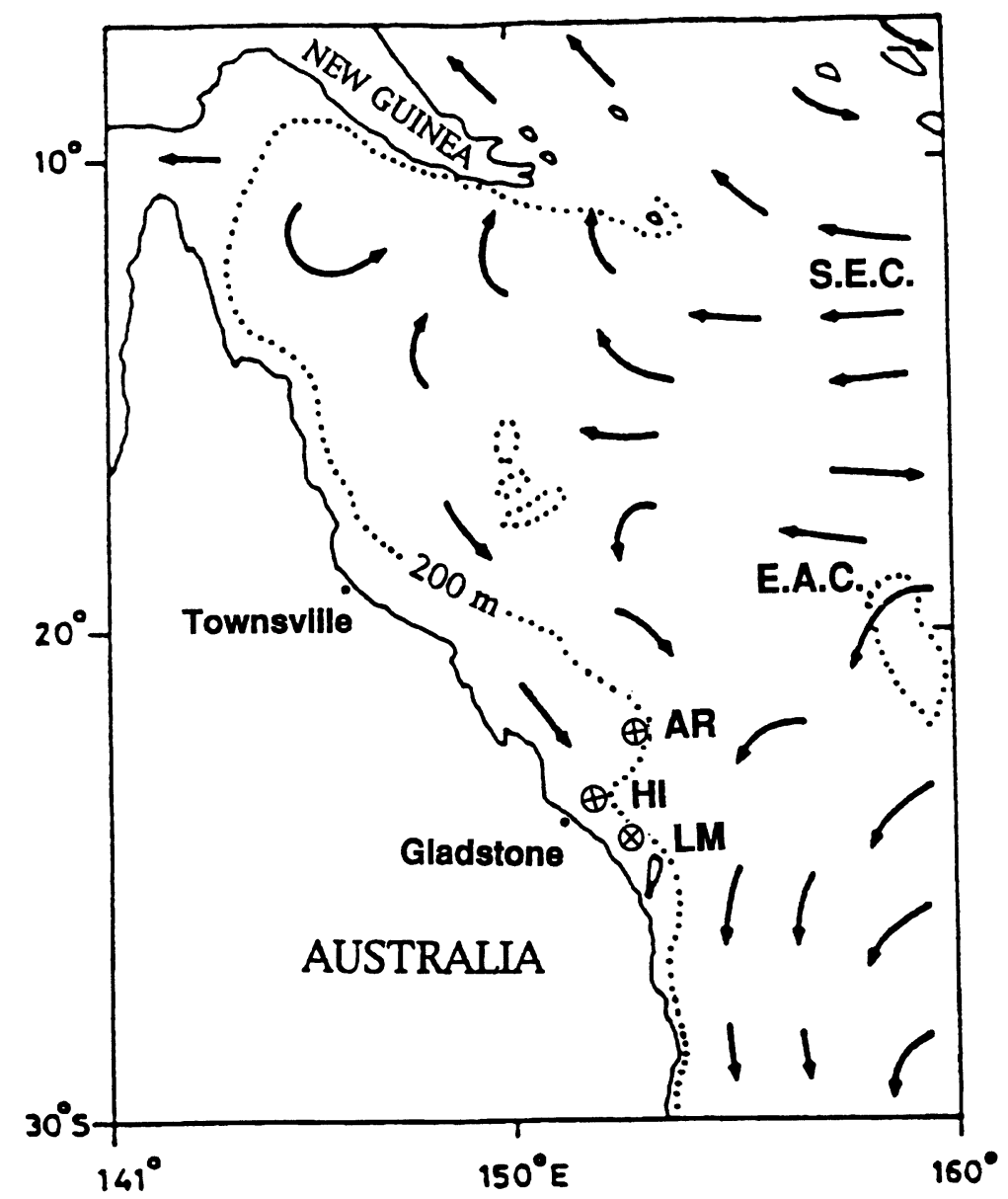

Fig. 3. Map of surface currents in the Southwest Pacific and area farther south during winter [adapted from Pickard et al. (1977: Fig. 63)]. Our three coral collection sites are indicated by $\otimes(\mathrm{AR}=$ Abraham Reef; $\mathrm{HI}=$ Heron Island; $\mathrm{LM}=$ Lady Musgrave $)$. 
Compared to coral $\Delta^{14} \mathrm{C}$ records from the equatorial and North Pacific, the Great Barrier Reef $\Delta^{14} \mathrm{C}$ record is delayed by ca. 2 yr during the 1960s and early 1970s (see Fig. 1; Druffel 1987). This agrees with measurements of tropospheric bomb $\Delta^{14} \mathrm{CO}_{2}$ (Levin et al. 1985; Nydal and Lovseth 1983) that showed a similar delay between the northern and southern hemisphere owing to the mixing time of the troposphere.

A correlation between low $\Delta^{14} \mathrm{C}$ values in Australian coral and El Niño/Southern Oscillation (ENSO) occurrences for the period AD 1635-1957 has been documented (Druffel and Griffin 1993). Most low $\Delta^{14} \mathrm{C}$ values for this pre-bomb period coincided with reported ENSO events (Quinn $e$ t al. 1987 ) for the eastern tropical Pacific. In our post-bomb data, it is difficult to discern lower $\Delta^{14} \mathrm{C}$ values during the 1957-1958 and 1965 ENSO events, as they were likely masked by the large influx of bomb ${ }^{14} \mathrm{C}$ to the surface ocean during this time. Subsequently, the $\Delta^{14} \mathrm{C}$ trends at Heron Island and Abraham Reef both decreased during the ENSO events of 1972-1973 and 1976-1977; they did not appear lower during the severe ENSO of 1982-1983.

Druffel and Griffin (1993) hypothesized that lower $\Delta^{14} \mathrm{C}$ observed during ENSO was the result of a higher relative input of waters from the South Equatorial Current (SEC) entering the southern Great Barrier Reef region during these events. The westward SEC flowed in the $10-20^{\circ} \mathrm{S}$ latitude band during the 1982-1983 ENSO, much further south than during normal years $\left(0-10^{\circ} \mathrm{S}\right)$ (Meyers and Donguy 1984; Wyrtki 1984). This would bring low $\Delta^{14} C$ equatorial waters from the SEC into the Coral Sea and further south.

Why were the $\Delta^{14} \mathrm{C}$ values not lower during the severe ENSO of 1982-1983? It is possible that the ${ }^{14} \mathrm{C}$ levels in the SEC were not low because of the cessation of upwelling for a prolonged period during the 1982-1983 ENSO. This is supported by the fact that none of the severe ENSO events of the past $100 \mathrm{yr}(1877-1978,1891$ and $1925-1926)$ were accompanied by low ${ }^{14} \mathrm{C}$ in the Abraham Reef coral (Druffel and Griffin 1993).

Nonetheless, the general observation of low $\Delta^{14} \mathrm{C}$ during most ENSO events is in contrast to the trends previously seen at locations to the east of the Great Barrier Reef. Our location is west of the so-called "shadow zone", where drought and cool sea water occur during ENSO, as opposed to warmer water and higher rainfall found to the east. These coral records provide an interesting antithesis that can be used in larger-scale studies of the timing of ENSO and the heat and water balances that are thrown out of steady state during these events (Druffel, ms.).

\section{Conclusion}

Seasonal cycles of stable isotopes in Heron and Lady Musgrave Island corals confirm the annual nature of density bands in Porites at these locations. $\Delta^{14} \mathrm{C}$ values at our South Pacific sites increased at a slower rate than those observed previously in corals from the northern hemisphere. There is regional variability of the post-bomb $\Delta^{14} \mathrm{C}$ signals observed at our three sites in the southern Great Barrier Reef. This variation is due to circulation differences between the coast (Heron Island) and open ocean (Abraham Reef) locales. The correlation between low $\Delta{ }^{14} \mathrm{C}$ and ENSO events in post1970 corals is likely due to the southward shift of the SEC and the increased input of low $\Delta^{14} \mathrm{C}$ water to the Coral Sea and Great Barrier Reef region. The exception is during severe ENSOs, such as the 1982-1983 event, when upwelling in the SEC could have ceased, causing normal ${ }^{14} \mathrm{C}$ levels in corals during these times. 


\section{ACKNOWLEDGMENTS}

We are grateful to Amy Witter and Nancy Parmentier for their expert assistance with the ${ }^{14} \mathrm{C}$ analyses at WHOI. We thank C. Eben Franks for the $\delta^{18} \mathrm{O}$ and $\delta^{13} \mathrm{C}$ measurements. Our thanks go to Peter Isdale and colleagues for collecting the Abraham Reef coral, and to Pete Sachs, Fraser Muir, Scott German, Trevor Graham, David Hopley and the staff of the Heron Island Research Station for their help with collection and initial preparation of the Heron and Lady Musgrave corals.

\section{REFERENCES}

Andrews, J. C. and Gentien, P. 1982 Upwelling as a source of nutrients for the Great Barrier Reef Ecosystems: A solution to Darwin's question? Marine Ecology-Progress Series 8: 257-269.

Burling, R. W. and Garner, D. M. 1959 A section of ${ }^{14} \mathrm{C}$ activities of sea water between $9 \mathrm{~S}$ and $66 \mathrm{~S}$ in the south-west Pacific Ocean. New Zealand Journal of Geology and Geophysics 2: 799-824.

Druffel, E. M. and Linick, T. W. 1978 Radiocarbon in annual coral rings from Florida. Geophysical Research Letters 5: 913-916.

Druffel, E. R. M. 1987 Bomb radiocarbon in the Pacific: Annual and seasonal timescale variations. Journal of Marine Chemistry 45: 667-698.

1989 Decade time scale variability of ventilation in the North Atlantic determined from high precision measurements of bomb radiocarbon in banded corals. Journal of Geophysical Research 94: 3271-3285.

(ms.) Circulation in the southwestern Pacific as invoked from pre- and post-bomb records of radiocarbon in Australian corals. In preparation.

Druffel, E. R. M. and Griffin, S. 1993 Large variations of surface ocean radiocarbon: Evidence of circulation changes in the southwestern Pacific. Journal of Geophysical Research 98: 20249-20259.

Edwards, R. L., Chen, J. H. and Wasserburg, G. J. 1987 ${ }^{238} \mathrm{U}-{ }^{234} \mathrm{U}-230 \mathrm{Th}-{ }^{232} \mathrm{Th}$ systematics and the precise measurement of time over the past 500,000 years. Earth and Planetary Science Letters 81: 175-192.

Griffin, S. M. and Druffel, E. R. M. 1985 Woods Hole Oceanographic Institution Radiocarbon Laboratory: Sample treatment and gas preparation. Radiocarbon 27(1): 43-51.

Levin, I., Kromer, B., Schoch-Fischer, H., Bruns, M., Munnich, M., Berdaun, D., Vogel, J. C. and Munnich, K. O. 198525 years of tropospheric ${ }^{14} \mathrm{C}$ observations in Central Europe. Radiocarbon 27(1): 1-19.
Meyers, G. and Donguy, J. 1984 South equatorial current during the 1982-83 El Niño. Tropical Ocean-Atmosphere Newsletter 27: 10-11.

Nozaki, Y., Rye, D. M., Turekian, K. K. and Dodge, R. E. $1978{ }^{13} \mathrm{C}$ and ${ }^{14} \mathrm{C}$ variations in a Bermuda coral. Geophysical Research Letters 5: 825-828.

Nydal, R. and Lovseth, K. 1983 Tracing bomb ${ }^{14} \mathrm{C}$ in the atmosphere. Journal of Geophysical Research 88: 3621-3646.

Östlund, H. G. and Stuiver, M. 1980 GEOSECS Pacific radiocarbon. Radiocarbon 22(1): 25-53.

Pickard, G. L., Donguy, J. R., Henin, C. and Rougerie, F. 1977 A Review of the Physical Oceanography of the Great Barrier Reef and Western Coral Sea. Canberra, Australian Government Publishing Service: 135 p.

Quay, P., Stuiver, M. and Broecker, W. 1983 Upwelling rates for the equatorial Pacific Ocean derived from the bomb ${ }^{14} \mathrm{C}$ distribution. Journal of Marine Research 41: 769-792.

Quinn, W. H., Neal, V. T. and DeMayolo, S. E. A. 1987 El Niño occurrences over the past four and a half centuries. Journal of Geophysical Research 92: 1444914461.

Rafter, T. A. $1968{ }^{14} \mathrm{C}$ variations in nature, Part $3,{ }^{14} \mathrm{C}$ measurements in the South Pacific and Antarctic Oceans. New Zealand Journal of Science 11: 551588.

Stuiver, M. and Polach, H. A. 1977 Discussion: Reporting of ${ }^{14} \mathrm{C}$ data. Radiocarbon 19(3): 355-363.

Toggweiler, J. R., Dixon, K. and Broecker, W. S. 1991 The Peru upwelling and the ventilation of the South Pacific thermocline. Journal of Geophysical Research 96: 20467-20497.

Wyrtki, K. 1984 A southward displacement of the subtropical gyre in the South Pacific during the 1982-83 El Niño. Tropical Ocean-Atmosphere Newsletter 27: 14-15. 